\title{
Method of Evaluating the Effect of Thread Lifting
}

GAIS score is generally used for evaluation of thread lifting effect (Table. 33.1). The contents of the GAIS score are as follows:

When interpreting the GAIS score, you have to keep in mind two facts. Firstly, the smaller the number, the better effect it means. Secondly, the GAIS score does not evaluate the effect objectively, but tells the degree of improvement subjectively.

It would be nice to measure the effect of thread lifting through an evaluation tool that is objectively quantified. Although not perfect, the judgment method using the Morpheus which will be talked about later can be a solution to objective result evaluation.
Table 33.1 Global Aesthetic Improvement Scale (GAIS)

\begin{tabular}{ll|l}
\hline Degree & Description \\
\hline $\begin{array}{l}\text { impreptional } \\
2\end{array}$ & $\begin{array}{l}\text { Very improved } \\
\text { patient }\end{array}$ & $\begin{array}{l}\text { Excellent corrective result } \\
\text { appearance, but not completely } \\
\text { optimal }\end{array}$ \\
\hline 3 & $\begin{array}{l}\text { Improved } \\
\text { patient }\end{array}$ & $\begin{array}{l}\text { Improvement of the appearance, } \\
\text { better compared with the initial } \\
\text { condition, but a touch-up is } \\
\text { advised }\end{array}$ \\
\hline 4 & $\begin{array}{l}\text { Unaltered } \\
\text { patient }\end{array}$ & $\begin{array}{l}\text { The appearance substantially } \\
\text { remains the same compared with } \\
\text { the original condition }\end{array}$ \\
\hline 5 & $\begin{array}{l}\text { Worsened } \\
\text { patient }\end{array}$ & $\begin{array}{l}\text { The appearance has worsened } \\
\text { compared with the original } \\
\text { condition }\end{array}$ \\
\hline
\end{tabular}

